\title{
COPING WITH COMPLEXITY AND TURBULENCE - AN ENTREPRENEURIAL SOLUTION
}

\author{
ROGER B MASON \\ Durban University of Technology \\ South Africa \\ University of Wolverhampton Business School \\ $U K$
}

This paper considers the adoption of an entrepreneurial orientation as a paradigm for companies operating in a complex and turbulent environment, viewing the environment as a complex and turbulent system in terms of chaos theory. Approaches suggested by chaos theory are compared with the entrepreneurial orientation to identify if such an orientation matches these suggested approaches.

Literature on chaos theory and entrepreneurship is compared, and a short case is presented, providing an illustration of how a company operating successfully in a complex and turbulent environment has used the principles of an entrepreneurial orientation.

The paper identifies considerable similarity between the management approaches suggested by chaos theory and the principles of the entrepreneurial orientation, indicating that chaos theory may provide the theoretical underpinning of the relationship between entrepreneurial orientation and turbulent environments. The case also shows how an entrepreneurial orientation has been successfully used in a complex and turbulent environment. The conclusion is that companies operating in a complex and turbulent environment could benefit from adopting an entrepreneurial orientation.

\section{INTRODUCTION}

Many companies have difficulty coping with the complex and turbulent external environments experienced today. Much of the literature in the field suggests that traditional bureaucratic models are unsuited to such turbulent environments (Costa, 1995; Farrell, 1998; Brown and Eisenhardt, 1998; Kelly and Allison, 1999). It also suggests that entrepreneurs flourish in complex and turbulent environments (e.g. Russell and Faulkner, 2004) and some literature focuses on how the entrepreneurial approach of small 
companies enable them to be more competitive in turbulent environments (Morris and Lewis, 1995; Halal, 1996). Although much has been written on the 'entrepreneurial orientation' (Ginsberg and Hay, 1994; Lumpkin and Dess, 1996; Yusuf, 2002; Alexandrova, 2004; Dess and Lumpkin, 2005), relatively little has been published suggesting an entrepreneurial orientation as a general approach for coping with complexity and turbulence. There is also a growing body of literature viewing entrepreneurship through the lens of chaos theory (e.g. Stevenson and Harmeling, 1990; Smilor and Freeser, 1991; Farrell, 1998; Peterson and Meckler, 2001; Russell and Faulkner, 2004). Since complex and turbulent environments are complex adaptive systems that are best understood through chaos theory, it might make sense to use chaos theory to better understand the link between entrepreneurship, the entrepreneurial orientation and complex and turbulent environments.

This conceptual paper therefore uses the chaos metaphor to match the characteristics of entrepreneurship to the characteristics of a complex adaptive system (the external environment) and then uses a short case as an illustration of how a company has applied such an entrepreneurial orientation to cope with its turbulent environment. This paper is important because most literature merely assumes the link between the entrepreneurial orientation and a turbulent environment and does not address it directly. To explain this link, the paper first discusses the changes being experienced in the external environment, paying particular attention to the competitive environment and methods for coping with the disruptive changes being experienced. Thereafter a brief explanation of chaos theory is provided, including some application of it to the field of business. Entrepreneurship and its use in complex and turbulent environments are then discussed and the short case is presented to illustrate the application of an entrepreneurial orientation in a complex and turbulent environment. Finally, an indication of how an entrepreneurial orientation could be effective in helping companies cope better in a complex and turbulent environment is provided, and recommendations are made for further research in the field.

\section{THE CHALLENGE OF CHANGE}

The environment of business is commonly discussed in terms of complexity (on a continuum from simple to complex) and turbulence (on a continuum from stable to unstable or dynamic) (Thompson, 1967; Smit and 
Cronje, 1992). This has also been discussed in the past in terms of lack of information, unpredictability and ambiguity. For a business to survive and grow in such an environment it must learn to cope with this complexity and turbulence (Yusuf, 2002). Business environments are becoming more complex and more turbulent. For example, as long ago as the early Nineties, McKenna (1991) maintained that the quantity and intensity of competition was increasing and growth in technology was leading to rapid obsolescence of products. This was supported by Chattell (1995), who saw customers' definitions of value becoming more volatile and short lived, leading to unpredictable and short product life cycles. Not only are the product life cycles becoming shorter and less manageable, but customers are becoming increasingly demanding (Schlossberg, in Zeithaml and Bintner, 1996). For many manufactured goods, product parity has been achieved and low price as a differentiating strategy has also disappeared. Customer service and customer relationships have therefore become vital to achieve any degree of competitive differentiation.

Morris, Schindehutte and LaForge (2002: 1) see the environment as "...consisting of increased risk, decreased ability to forecast, fluid firm and industry boundaries, a managerial mindset that must unlearn traditional managerial principles, and new structural forms that not only allow for change, but also help create it". Many companies are unable to adapt the functioning of their organisations to the requirements of their increasingly turbulent and competitive environments (Halal, 1996). In such a situation, the company that can more quickly and more effectively adapt their marketing and management activities to the changing environment is more likely to be able to build and maintain a sustainable competitive advantage.

\section{THE COMPETITIVE ENVIRONMENT}

The highly competitive environment that Halal (1996) mentions is the result of three factors, namely, increased competition, technological change, and increased customer expectations.

First, competition has intensified with the arrival of global competition. Globalization has created a new set of demands in the form of converging customer needs, international buying groups and falling trade barriers (Birkinshaw, 1995). Second, the speed with which technology is evolving is facilitating quicker translation of new technologies into successful products and methods of operation. In order to take advantage of 
these technologies the businessperson needs to generate an organisational climate and philosophy that supports and encourages technological advances (Lazer et al, 1990). Last, the increase in customer expectations is the result of increased availability and accessibility of options and knowledge (Birkinshaw, 1995).

Many authors feel that in such 'chaotic' environments, traditional management approaches are inappropriate, and that new methods informed by the new sciences, such as chaos theory, are required (Stacey, 1996; Brown and Eisenhardt, 1998; Briggs and Peat, 1999; Kelly and Allison, 1999; Koch, 2000). Organisations need to be capable of meeting demands for speed, multi-dimensionality, flexibility, and innovation (Pinchot and Pinchot, 1994; Birkinshaw, 1995). However, the majority of companies' organisational structures and managerial principles do not lend themselves to meeting these demands (Bartlett and Ghoshal, 1995). For example, in 1992, General Motors, IBM, and Sears lost a total of $\$ 32,4$ billion, as they were unable to adapt to the changing environment. As competition became more intense, instead of focusing on the factors that limited their ability to pursue the opportunities of the new environment, these companies directed their energy into finding "temporary band-aids" to protect profits (Pinchot and Pinchot, 1994: 14). Therefore, the problems that large corporations face stem, at least in part, from sticking to past success formulae well beyond the limits of their usefulness (Bartlett and Ghoshal, 1995). Furthermore, the work of Courtney, Kirkland and Viguerie (1997) highlights that the tools for analysing an uncertain, or ambiguous, environment are not the tools with which most business people are familiar. It is, therefore, doubtful whether the traditional management techniques, which are based on an assumption of linear relationships, and thus predictability, can be effective in such complex, turbulent and uncertain environments. New approaches are needed, and these may be found in the growing application of the new sciences, including chaos theory, to business and management. As far back as the early Nineties, Stevenson and Harmeling (1990) were writing about entrepreneurship in terms of chaotic theory and Smilor and Feeser (1991) applied chaos theory to the factors that contribute to entrepreneurial behaviour. Bouchikhi (1993) maintains that chaos theory was not too helpful in understanding the entrepreneurship process, but then goes on to describe entrepreneurial success as an emergent phenomenon and a process that is non-linear and subject to chance events. This implies a degree of complexity in the process. More recently, chaos theory has been applied in tourism due to its "complex, multi-faceted nature" (Russell and Faulkner (1999: 413). Russell and 
Faulkner (2004) also argue that an understanding of entrepreneurship in the tourism industry is more appropriate through a chaos theory approach. Peterson and Meckler (2001) support this applicability of chaos theory to entrepreneurship, and maintain that the inclusion of chaos into the entrepreneurial process improves prediction models. They suggest that the classic ideas of chance playing a role in entrepreneurship can be better understood if seen as a random appearing, but actually a complex, phenomenon, and that, therefore, chaos theory should be used to understand entrepreneurship. This implies that chance, or luck, which is often mentioned as an important factor in entrepreneurship, may not be random, but may be a factor that follows a certain pattern, namely a phenomenon occuring within certain limitations or boundaries, as explained by the strange attractor of chaos theory. Thus, if the 'pattern' can be identified then some prediction is possible, whereas it is not possible if entrepreneurial actions or success is too dependent on luck or chance. Therefore, in the next section, chaos theory will be explained.

\section{CHAOS THEORY}

Chaos theory owes its origin to the work of Lorenz, who, in attempting to develop a long-range weather forecasting technique, discovered an underlying pattern in seemingly random data (Gleick, 1988). Subsequent research in fields as disparate as biology, medicine, and economics has shown that these underlying patterns or structures exist in most, if not all, complex systems. The behaviour of these systems range from totally predictable on one end of a continuum to totally random and unpredictable on the other. Waldrop (1992) classifies these extremes as order and chaos, while Stacey (1992) refers to them as stability and explosive instability. 'Chaos' or 'explosive instability' is another way of describing extremely complex, turbulent and uncertain environments.

One of the most significant of chaos research findings is that, in moving from order at one end of a continuum to chaos at the other end, a system goes through a phase that Waldrop (1992) termed the 'edge-of-chaos', and which Stacey (1992) termed 'bounded instability'. In other words, in going from order to chaos, a business environment would go through a transition that is at the edge-of-chaos or bounded instability. In this process of going from stability to turbulent complexity (explosive instability or chaos), it would not be possible to predict the change from stability using the traditional tools of forecasting, scenario planning, etc. as these base 
their predictions on the stable state. However, using chaos theory research, it might be possible to identify the patterns that exist at the phase transition. Stacey's (1992) bounded instability explains that behaviour is predictable within certain boundaries (i.e. within a 'pattern' of behaviour), but the actual patterns that emerge cannot be predicted. They can only be observed and recognised as they emerge because of self similarity, that is, they will be similar to, but not the same as, past patterns (Stacey, 1995). Therefore, experience and knowledge of the history of the company, industry, etc. are important. It is at this point that small actions can escalate into major outcomes through the chaos principle of sensitive dependence on initial conditions, and therefore swift or pre-emptive action can prevent or amplify the phase transition that is taking place at the edge-of-chaos.

Systems subject to chaos have the ability to amplify small differences in the starting position of a system, thus making it very difficult, if not impossible, to predict the final outcome of the system (Edgar and Nisbet, 1996). This is known as sensitive dependence on initial conditions (Gleick, 1987), or as the 'nudge' effect when referring to business systems (Nilson, 1995). According to Nilson (1995: 40) "a small change in one part of a system can aggregate into a major change somewhere else because it triggers systems to change." This is counter-intuitive, as small initial conditions in business are often ignored as being unimportant, and only large or major issues are considered, especially in strategic planning. According to chaos theory, however, these small events are very important, firstly because they are usually overlooked, thereby leading to unexpected or discontinuous change, and secondly, because they provide opportunities for 'nudging' or influencing a system, especially by a small business, in such a way that it becomes more predictable, or controllable.

Another characteristic of chaos theory is the strange attractor, which is the output of a mathematical and graphical recording of a system at many points in time or space. In systems that are in chaos, or explosive instability, it is impossible to predict where the system will be next because it is totally random. However, in the edge-of-chaos state the system will always fall within certain boundaries, creating the 'strange attractor'. This explains Stacey's (1992) term bounded instability. It also explains that, if a system is at the edge-of-chaos, it can be predicted to fall, or behave, within certain boundaries, but without any certainty of where exactly within those boundaries it will fall, or how exactly it will behave. Being able to maintain a system, or in the business sense, an environment, at the edge-of-chaos is important because activities at the edge-of-chaos are dynamic and lead to growth and development. This is because stable organi- 
sations are, by definition, focussing on the past, which is not where the creativity, innovation and new products and processes required of entrepreneurial firms are to be found. The opposite of operating at the edge-ofchaos is order and stability, which leads to decline and death, or in business terms, stagnation, loss of market share and eventual demise of the business. Thus, a business that seeks, and operates successfully in, an environment at the edge-of-chaos also has a distinct advantage over a company that continually seeks stability and equilibrium. It is continuously looking for new ways to grow and adapt. Innovation and creativity is thus generated at the edge-of-chaos.

As we have seen above it is very difficult to predict exactly the 'next position' of a system. In an 'open system', such as a market, it is even more difficult, if not impossible, due to the interaction of the internal variables, the external environmental variables and the non-linear nature of open systems. However, in a stable system, outcomes of the system are likely to be very similar, but not identical (Young and Kiel, 1997). As the system goes through transitions, the number of potential outcomes increases exponentially, so similarity of the positions decreases, and predictability decreases, until the system's behaviour is totally random, having passed beyond the edge-of-chaos. However, when the system is in a stable or ordered state, or more interestingly, in an edge-of-chaos state, the next position can be predicted within specific boundaries, because complex systems tend to replicate their systems at different levels. Thus, it makes sense to seek similarity rather than sameness. In other words, routine or repetitive management or marketing actions are doomed to failure, as they will not be able to effectively address an environment that is similar, but not the same. What is required is an organisational style that is able to change and adapt rapidly, but because of self-similarity, the changes will not need to be dramatic or totally different. This is a process which, according to Stacey (1996: 201), is a "...kind of spontaneous selforganization and creative destruction at an organizational level".

\section{IMPORTANCE OF CHAOS THEORY FOR BUSINESS}

Chaos theory, the study of the non-linear dynamics of complex systems, has much to contribute to the understanding of businesses in complex and turbulent environments. Most of the literature on environmental complexity and turbulence discusses it in terms of traditional models and methods of analysis. Since increasing complexity and turbulence appears to be in- 
herent in most non-linear dynamical systems, it makes sense, therefore, to make use of the chaos theory metaphor in investigating companies' reactions and adaptations to complex and turbulent environments. This becomes even more important when it is realised that increasing complexity appears to be a characteristic of open systems, which continually reorganize to increasingly higher levels of complexity (Combs, 1995).

Since business environments can be concluded to be systems in 'farfrom-equilibrium' states, which by their very nature continually increase in complexity, it is essential for management to identify activities which are effective in managing complex systems in such turbulent environments. A variety of authors have suggested different activities for managing in turbulent environments. Young and Kiel (1997) and Phelan (1995) propose the development of learning organisations, as they can react rapidly to turbulent environments. Similarly, Emery and Trist (1965), Achrol (1991) and Volberda (1997) suggest flexible, quick reacting, boundary spanning organisational structures, which also enable quick reaction to environmental change. These suggested activities are predominantly reactive.

Other authors suggest a more proactive approach. For example, Young and Kiel (1997) suggest keeping systems small, as they are more sensitive to local conditions and can not only react quicker, but because management are closer to 'the coalface', they are more likely to see the changes developing, and thereby anticipate the required adaptations. This is supported by Doherty and Delener (2001), who show that, as a system or organisation increases in size, the less predictable its behaviour becomes, and as a result, responses to actions are abrupt and discontinuous.

A third type of activity for managing turbulent environments is one that encourages individual action and initiative, rather than planned, organisational action. Glass (1996) and Courtney, Kirkland and Viguerie (1997) suggest that providing vision or strategic intent, rather than strategic plans, enable individuals to react quickly and appropriately to changes. Stacey (1992) supports this approach, believing that complexity and turbulence is best handled by encouraging innovation and spontaneity in people. This approach is extended by Morris, Schindehutte and LaForge (2002: 13), who suggest an approach they call entrepreneurial marketing. Marketing is seen as art, based on the "imagination, vision, cleverness, and originality" of entrepreneurship. In addition to greater adaptability and flexibility, entrepreneurial marketing enables the marketer to redefine environmental conditions.

In addition to the above approaches, many chaos researchers believe 
that the best way of controlling chaos is with chaos (e.g. Brooks and Weatherston, 1997; Brown and Eisenhardt, 1998). This is supported by research conducted in the field of biology (Evans, 1998), which found that the human animal has an innate ability to act at the edge-of-chaos. Thus, it could be that human beings, if not too strictly controlled, have a natural ability to create the chaos that is required to cope with an extremely complex and turbulent environment. In other words, bottom-up, emergent responses to environmental change might be the most effective method of coping. For example, Lichtenstein (2000) found that the most effective approach in a turbulent environment was to push control down in the organisational hierarchy and allow the organisation to self-organise in response to environmental challenges. Farrell (1998) believes that you should inject complexity into a system at the point where you can cope with it best. Fradette and Michaud (1998) stress that this injected complexity should create discontinuities for competitors but not for the company itself, and D'Aveni (1999) has shown that, in turbulent markets, the most disruptive and unconventional company tends to be more successful. This may well be because, as proposed by Doherty and Delener (2001: 72), the best position for a firm in a complex and turbulent market is balancing at the edge-ofchaos. This, they maintain, is because the "...ability to process information, to explore strategies and to evaluate results" is maximised at the edge-of-chaos. Furthermore, operating at the edge-of-chaos is important because the most dominant competitor in a system, or market, is the most likely to go out of business, because their dominance encourages the status quo and thereby prevents them from seeing the need to change.

\section{FUNCTIONING IN A COMPLEX AND TURBULENT ENVIRONMENT}

From the above discussion, an approach for coping with a complex and turbulent competitive environment can be summarised as follows:

A small organization that is innovative, flexible, spontaneous, and boundary spanning, and which creates dynamic chaos or disequilibrium in its environment through the use of destabilising management and marketing tactics. Its smallness and boundary spanning activities make it sensitive to local conditions and enable it to react quicker in its turbulent environment than its large, bureaucratic competitors. 
The traditional approach to business is not consistent with the abovesuggested approach, and therefore may not be the best method for operating in a complex, turbulent environment. In other words, detailed strategic, operational and tactical plans, formal management, centralised decision making, tight control of all operations by management, and striving for growth and ever-larger organisations is unsuited to a complex and turbulent environment. Thus, the 'command and control', scientific or Taylorist style of management may no longer be applicable due to the fundamental changes which have been experienced in many business environments over the past twenty to thirty years. Unfortunately, this management style has proved enduring and still persists in many companies (Burnes, 2004).

In order for businesses to cope with these changes, and to adopt the above approach, a new business paradigm is required (Luczkiw, 2002). Edgar and Nisbet (1998: 4) suggest a focus on "an innovative, creative, spontaneous and learning form of organisation and approach to strategy." They further imply that this will be found in small, entrepreneurial organisations. This is supported by Hammer (in Gibson, 1997: 100) who believes leaders of future organisations "will not be bureaucratic managers who have risen through the ranks. They will really be entrepreneurs, even in a large organizational setting." Centralized and hierarchical management is too bureaucratic, slow and expensive for dynamic and turbulent environments (Gault and Jaccaci, 1996). Learning organizations that, amongst other things, encourage creativity and entrepreneurship, are necessary.

The above discussion reveals that entrepreneurship could be a suitable method of addressing the problems faced by companies in increasingly complex and increasingly competitive environments, and therefore a suitable replacement for the bureaucratic style of management. However, before suggesting that companies adopt entrepreneurship as a paradigm, the most effective way of realising an entrepreneurial orientation needs to be identified. In order to do this, entrepreneurship needs to be defined and discussed.

\section{ENTREPRENEURSHIP DEFINED}

Further discussion of entrepreneurship and the business organisation requires clarification of what is meant by entrepreneurship. Although there 
has been considerable debate over the exact definition of entrepreneurship, there is consensus that entrepreneurs perform the function of identifying opportunities and giving them economic value (Muzyka, De Koning and Churchill, 1995). Furthermore, there appears to be consensus that entrepreneurial activity increases when environmental uncertainty is high, and the effect of this uncertainty on entrepreneurship varies across industries and may vary across countries (Yusuf, 2002).

Much of the literature on entrepreneurship focuses on the characteristics that define entrepreneurs and the nature of entrepreneurial talent (Chell, Haworth and Brearley, 1991; Jennings, 1994). However, the process of entrepreneurship, rather than just the traits of entrepreneurs, is also important for understanding entrepreneurship (Ginsberg and Hay, 1994; Lumpkin and Dess, 1996). This is supported by Bouchikhi (1993), who criticises the 'check-list' approach of looking for understanding of entrepreneurship in lists of personality, strategic or environmental factors, and who proposes a process approach of combining entrepreneurs, environment, chance and outcome into a complex framework.

With regard to the specific dimensions of the entrepreneurial process, Miller (1983, in Lumpkin and Dess, 1996) proposes characteristics of an entrepreneurial firm. These are a willingness to innovate, to take calculated risks and to be proactive relative to the marketplace. Lumpkin and Dess (1996) expanded on these characteristics, including competitive aggressiveness (which they maintain is suggested by Miller) and autonomy. These five characteristics have been adopted as the defining aspects of an entrepreneurial orientation by authors such as Bruining and Wright (2002), Morris, Schindehutte and LaForge (2002) and Alexandrova (2004). The importance of this orientation in a turbulent environment is supported by the fact that the external and internal environments are determinants of the entrepreneurial orientation (Aloulou and Fayolle, 2005). The five characteristics of the entrepreneurial orientation are explained below.

Innovation reflects an organisation's tendency to engage in and support new ideas, which may result in new products, services or technological processes. It is a willingness to depart from existing technologies or practices (Lumpkin and Dess, 1996). Osborne (1995:1) refers to this as "an inclination to test - and sometimes ignore - conventional wisdom about how things are done..."

Being proactive, or taking initiative, is pre-empting future problems, needs or changes. It is a forward looking perspective that is accompanied by innovative or new venturing activity. It is a process that anticipates and acts on future needs by seeking new opportunities that may, or may not, be 
related to the present line of operations; for example, introducing new products and brands ahead of the competition, or strategically eliminating operations that are in mature or declining stages of their life cycle (Lumpkin and Dess, 1996). Osborne (1995: 8) summarises this by saying "The entrepreneur must have the prerogative and resources to initiate riskbearing actions."

Competitive aggressiveness is an organisation's propensity to directly challenge its competitors to achieve entry, or an improved position that outperforms industry rivals in the marketplace. It also reflects a willingness to be unconventional rather than rely on traditional methods of competing. Farrell (1993:141) illustrates this feature by saying, "High-speed innovation is the entrepreneur's number one competitive weapon - and it's virtually free. Every entrepreneur dreams of competing with the biggest and the slowest." Thus competitive aggressiveness, which refers to a firm's responsiveness directed towards achieving a competitive advantage, is an important component of the entrepreneurial orientation (Lumpkin and Dess, 1996).

The concept of autonomy is a key dimension of an entrepreneurial orientation. Autonomy refers to the freedom from organisational constraints in order to act independently, thereby encouraging creativity and innovation. "Strong leaders, unfettered teams or creative individuals who are disengaged from organizational constraints" provide the autonomy required for driving new ventures and new entry activities (Lumpkin and Dess, 1996: 140). Chell, Haworth and Brearley, (1991: 28) say that the "entrepreneur is not simply an overseer, a superintendent or a 'caretaker', he actively pursues and initiates change." Bruyat and Julien (2000) support the importance of autonomy, highlighting the role of the individual in the creation of new value through the ability to learn, create and to have freedom of action; that is, not merely an automaton reacting to the environment.

As mentioned earlier, relying only on 'entrepreneurial characteristics' to understand entrepreneurship is not enough. Understanding the 'entrepreneurial process' is essential, and Alexandrova (2004) explains that the entrepreneurial orientation is related to the entrepreneurial process since it has to do with entrepreneurial action, such as destroying old business practices, designing new market entries and establishing new patterns of behaviour. The entrepreneurial orientation can thus be considered a bridge between the characteristics of entrepreneurship and the entrepreneurial process. Peterson and Meckler (2001), in their study of immigrant entrepreneurship, suggest three levels of entrepreneurial process, with each 
continually changing and interacting with, and changing, the other levels clearly a complex process and one that chaos theory could help to understand. The first level in their model involves individual forces, which are typical of the individual characteristics discussed previously. The second level involves group or community level forces, such as a social group that provides support or resources (labour, capital, knowledge) to the entrepreneur. Thirdly, the environment level is represented by other general forces that encourage or restrict entrepreneurship. Although this may be a good model for researching entrepreneurship, it does not, in itself, help us to understand what entrepreneurship is. Russell and Faulkner (2004: 559) do this better by indicating that change, turbulence and instability are the entrepreneur's "favoured operating environment, and if it does not already exist, they set about creating it. It is often through times of upheaval, when there exists an edge-of-chaos state, that entrepreneurs spot opportunities in the environment and use their creativity to bring about innovation." This involves human choice, dynamism, discontinuity and holistic handling of numerous variables. This undoubtedly shows entrepreneurship as a complex and non-linear process, and therefore possibly suitable for managing a complex and turbulent environment in terms of the principle of 'only chaos can control chaos', as discussed previously (Evans, 1998; Farrell, 1998; Fradette and Michaud, 1998; D'Aveni, 1999). This was supported by Yusuf's (2002) findings that suggested that environmental uncertainty is best addressed with entrepreneurship, regardless of industry sector, firm size or age, or geographic location. Weaver et al., (2002) in fact stresses that entrepreneurs prefer a turbulent environment, and that trying to reduce environmental uncertainty could result in a reduction in entrepreneurship. This is also implied by Yusuf (2002) who maintains that an entrepreneurial orientation is a conscious reaction to a turbulent environment.

It could be argued that the available literature adequately justifies the use of an entrepreneurial orientation in a turbulent environment, but it does not adequately explain why this might be so. Chaos theory might be the underlying theory that explains how and why the entrepreneurial orientation enables firms to more effectively cope in turbulent environments. This is important as the adoption of entrepreneurial orientation has not always been successful. 


\section{LIMITATIONS OF ADOPTING AN ENTREPRENEURIAL ORIENTATION}

Companies that have attempted to adopt an entrepreneurial orientation have used strategies such as partnerships, acquisition of small businesses, corporate venturing, and intrapreneurship (Ginsberg and Hay, 1994). However, these have often proved unsuccessful as the companies adopted strategies without first changing the organisational structures and management processes that drive the strategies. These strategies do not successfully address the paradoxical need of an efficient organisation that allows the freedom to be entrepreneurial (Bartlett and Ghoshal, 1995).

In the past, companies have also attempted to modify their organisational structures and management systems through downsizing, decentralisation, and networking (Muzyka, De Koning and Churchill, 1995). Although the changes resulted in flatter, more decentralised organisations, they were still essentially bureaucratic and therefore "lacked the systems for assembling a collective intelligence to ensure a sustainable competitive advantage" (Pinchot and Pinchot, 1994: 2).

Furthermore, it may be probable that the entrepreneurial orientation is only really effective when applied in a complex and turbulent environment, and some of the failed implementations may have been because of attempts to use it in simple and stable environments. However, it could be argued that almost all environments are more complex and turbulent today because of the impact of increased competition, globalisation and information communications technology as was discussed earlier. Therefore, the entrepreneurial orientation is probably very widely relevant in business environments today.

What then does chaos theory have to say about the strategies, structures and process required for successfully adopting an environmental orientation?

\section{MANAGEMENT METHOD FOR AN ENTREPRENEURIAL ORIENTATION}

Companies such as Hewlett-Packard and 3M have successfully converted their organisational structures to enable them to adopt an Entrepreneurial Orientation. The similarities of these companies reveal core competencies of a successful entrepreneurial organisation. These include a philosophy of entrepreneurship that promotes innovation and new ventures (Dess and 
Lumpkin, 2005). For example, $3 \mathrm{M}$ allow managers to move from one business unit to another without bureaucratic obstructions and allows them to obtain funding for their ideas from other departments - the focus is on the ideas rather than on the policies and procedures (Tetenbaum, 1998). Furthermore, such companies are built around relatively small units that operate as an internal market economy (Foxall and Minkes, 1996). This is consistent with the proposition that small business units are most effective for turbulent and complex environments (Young and Kiel, 1997; Doherty and Delener, 2001). A further similarity in these companies is that entrepreneurship is diffused throughout the organisation. Although all business units are differentiated according to the tasks they perform, such as field sales, product creation, or industry marketing, they all share a common vision: to think and act as companies in a networked holding, being independent, and using each other's resources to achieve their own goals. Gault and Jaccaci (1996: 36) support this 'common vision' by stressing that "the aim of the organization is so internalized in its members that the higher-order unity held by all, guides the action of all." This is much like the plan for a living entity being held in its DNA. In fact, some authors have begun referring to this as corporate DNA, which Baskin (1998: 91) defines as a "flexible, universally available database of company procedures and structures." This corporate DNA is built from past history and Baskin believes that people act in ways to fulfil a company's identity due to the corporate DNA.

These small business units form an internal market economy that is designed to produce continual and rapid structural change, just as external markets do. This cooperative cluster of internal enterprises provides the creativity of a small business venture, yet has the economic power of a large corporation. Control is maintained, because each unit is responsible for controlling its own performance in return for freedom of operations (Halal, 1996). Hewlett-Packard is famous for its entrepreneurial system, which holds units accountable for results, but gives them wide operating latitude. As one Hewlett-Packard executive described it, "The financial controls are very tight, what is loose is how people meet those goals" (Halal, 1996: 36). This sharply focused understanding enhances both control and freedom, providing two major strengths: all units are accountable for results and entrepreneurship is encouraged, so that, according to Achrol (1991: 59), "technologies, skills and individuals can move freely among units and be organized rapidly around problems and solutions".

Lastly, entrepreneurship is diffused throughout the organisation (Foxall and Minkes, 1996). It is not confined within any particular business 
function. For example, at $3 \mathrm{M}$ the entrepreneurial resources are the regular company employees who are stimulated to be more creative and innovative in their everyday work (Pinchot and Pinchot, 1996). New recruits, with their managers, participate in a training course on risk-taking in which they are taught how to defy their managers and how to achieve goals despite the opposition of superiors (Tetenbaum, 1998). Therefore, the entrepreneurial company is a company built around a core entrepreneurial process that drives everybody in the organisation and everything the company does (Muzyka, De Koning and Churchill, 1995). This, too, is consistent with the idea of corporate DNA.

To implement this entrepreneurial orientation, front line entrepreneurs, who are responsible for creating and pursuing new growth opportunities, must be empowered and trained to recognise the need for change and to manage change on an ongoing basis (Bartlett and Ghoshal, 1995; Muzyka, De Koning and Churchill, 1995). Corporate leaders should establish an overall mission or vision for the company that defines the parameters (boundaries) within which the entrepreneurial initiatives must be contained. Examples of this include Boeing's commitment to take risks to push technological advancement and 3M's stressing innovation and solving real human problems with original ideas (Tetenbaum, 1998). CEO's continually stress and reinforce these statements of values, purpose and principle. They should also set the performance standards that must be met, such as 3M's $15 \%$ of revenue must come from new products (Tetenbaum, 1998) or Akamai's rule that customers' questions must be answered on the first call or e-mail (Eisenhardt and Sull, 2001). Bartlett and Ghoshal (1995) stress the importance of corporate leaders emphasising to all entrepreneurs that no single entrepreneur could afford to own or control all the expertise, resources, or services necessary for independent survival, and that their success is dependant on the interdependence of the entrepreneurial organisation.

\section{CASE - ACME-PAC}

In order to illustrate the suitability of an entrepreneurial orientation for a turbulent environment, a short caselet about a company operating in the packaging industry in South Africa will be discussed. To protect the identity of the company, the artificial name of ACME-PAC is used. 
Coping with Complexity and Turbulence...

\section{Methodology}

To develop the case an instrumental case study approach was used in order to "provide insight into an issue or refinement of theory" (Denzin and Lincoln, 1994: 237). Such an approach is suitable for exploratory research (Lee, 1999). The selection of the company for the case study was based on a Delphi forecasting approach, which is suitable when being used by experts (Roberts, 2000; Caldwell, 2000). A panel of five packaging industry experts (consultants, journalist and packaging buyers) was formed and via the iterative Delphi approach ACME-PAC was identified as a successful, entrepreneurial company in a turbulent sector of the packaging industry. An appointment was made with the Managing Director and suitable interbiewees were agreed with him. Data was collected via depth interviews, based on an interview guide, with all the management in the company as well as the sales representatives; seven interviews in all. The interviews were audio recorded and transcribed into typed documents. An inductive form of analysis was used, deconstructing the transcripts and reconstructing according to patterns of commonalities or differences in the data.

\section{Findings}

The external environment in which ACME-PAC operates is experiencing an escalating rate of change equal to, and probably greater than, that seen elsewhere (Weeks, 1990; Puth, 1996). Burgess (1998) believes that this turbulence, complexity and competitive intensity will increase even further. ACME-PAC is a small company operating very successfully in the most dynamic sector of the packaging industry. The company was started by a packaging industry entrepreneur some years ago, and has won numerous awards for entrepreneurship. The company has now reached the stage where formal systems are becoming necessary.

Although ACME-PAC clearly operates in a complex and turbulent environment, different opinions are held about, and different interpretations are made of, the degree of turbulence or stability in their environment. It appears as if the technological component of the environment, including product development, is very turbulent, with other components being seen as less turbulent. Generally, they react to the turbulence with controlled change in order to bring the system, or company, back to an equilibrium position, from a state that may have been heading towards turbulence and chaos. 
However, these attitudes to turbulence are not consistent with the way ACME-PAC handles change. Although they do not change rapidly as a matter of principle, when such rapid change is required, they are capable of changing, and willing to change, very quickly. Their emphasis on speed and fast turnaround times emphasises their desire to be proactive and to keep ahead of the market. They do not just meet customers needs, but initiate new products and processes, thereby 'pulling their customers along and into the future.' Furthermore, they disrupt their environment to develop a competitive advantage, as was reflected by a comment by their Sales Manager - "(I) would say that disrupting the market is one of the key strategies, key ways of operating". Examples of such disruptions included introducing innovative new products and achieving response and turnaround times that are way ahead of, and amaze, the rest of the industry. Thus, they appear to encourage stability, except when it suits them to destabilise! This is consistent with the work of Farrell (1998) and Fradette and Michaud (1998). ACME-PAC are able to cope with the occasional instability that such destabilising action causes, and then are proactive in rapidly restoring stability. This indicates that they cope with turbulence from the environment, or turbulence instigated by themselves, by taking advantage of conditions caused by the turbulence and then rapidly restabilising the situation. This innovative approach is consistent with a company proactively facing change and trying to keep ahead of its market, which is to be expected of a creative, innovative and adaptive organisation that takes a flexible and entrepreneurial approach to its business. This appears to be a very suitable method for an environment that is fundamentally stable, but that has pockets of turbulence and rapid change in it. It is, furthermore, suitable for a company that is prepared to institute significant changes to keep itself ahead of the competition. It should be noted, however, that although they are very competitive and are prepared to disrupt the market, they are not overly aggressive towards competitors. In fact, they prefer to work with some competitors by forming strategic alliances.

ACME-PAC see themselves as a specialist company, with everything they do being dynamic, innovative and unique. They are the leader in their market, initiating methods and techniques that other companies in their market follow. These innovative approaches are also applied to management methods, which are open and transparent. Their view is that everyone can contribute and that motivation and commitment can be generated through involvement. As a result, structures are loose and overlap and people can get involved in, and comment on, any aspect of the business. Individuals are also given full responsibility for their areas in order 
to 'breed decisiveness'. They employ people who are independent 'selfstarters', and who are encouraged to be entrepreneurial and to act independently, as is shown by the emphasis on 'individual responsibility' in their mission statement. Lower level staff, who have been given the responsibility, are trusted by management to take decisions relevant to their operational area. ACME-PAC's encouragement of responsibility empowers staff and encourages independent action, which they believe makes their company more successful. This management style has also resulted in different attitudes towards discipline and control. The freedom allowed by ACME-PAC does not imply a lack of discipline or control. The vision and culture of the company institutes self-control and helps to clarify what the decision should be. Furthermore, management are open for advice, especially since they have many young and relatively inexperienced employees in management positions. This democratic management style and the culture of the company enables this autonomy and responsibility to be managed and not to result in a totally laissez faire attitude. Financial matters are fairly tightly controlled and the freedom and self-management also is fairly strictly controlled, albeit through self control, via the clear vision and culture that imposes a fairly high degree of conformity to the overall corporate goals.

This management style encourages an entrepreneurial approach amongst all staff. The degree of openness and transparency is involving of staff. This is indicated by the fact that ALL staff attend the quarterly meeting at which the financial results are openly presented. In this meeting, staff question management on any matters and are candidly answered. In one meeting attended by the researcher, staff challenged the Managing Director about an employee who had been retrenched and negotiated with him in the meeting for the employee to be reinstated under agreed terms. Furthermore, although there is a fair amount of formal communication in ACME-PAC, they also encourage lots of informal communication, especially via the canteen. There are very few written policies and procedures, as is indicated by the following quote by a manager: "There are no rules. There are no formal procedures". This is to be expected, as they are creative and entrepreneurial, characteristics that do not lend themselves to systems that are more formal.

ACME-PAC's strategic planning is a continuously evolving process, growing, changing and developing based on changing environmental factors. This is very much the approach that would be suggested by chaos theory. Although they do not see their environment as excessively turbulent, this planning approach may be successful because their environment 
is sufficiently turbulent to warrant a less formal, destabilising, type approach. Their strategies are 'extremely focussed' but without a written plan. Although projects are carefully planned, the overall corporate strategy is not. It is based on a clear vision and idea of whom they are and where they want to go. It is thus short term, continually monitoring the environment and maintaining the flexibility to adapt quickly to any anticipated changes. They try to be different in their strategic approach - a maverick - and to continuously look for new ways of doing things. In other words, they adopt innovative strategies and fully understand the use of adaptation as a strategy in order to cope with changes and competition in their market.

\section{Discussion}

This case reflects a company that copes with a turbulent environment (even though they do not perceive it as particularly turbulent) by adopting Lumpkin and Dess' (1996) principles of an entrepreneurial orientation. Their innovation is shown throughout the organisation and its processes, and by the way they lead the market in marketing and technological approaches. Their proactiveness is shown by their leading the market and by destabilising it when necessary. They create their own market environment. Autonomy is shown by the way they lead the market and, individually, by how staff members are given responsibility and authority, and the degree to which they devolve responsibility and decision-making. Their risk-taking nature is reflected in their willingness to destabilise the market when necessary, in the fact that they lead the industry in technological development, and in the fact that they are prepared to devolve responsibility throughout the organisation. The one entrepreneurial characteristic that seems to be lacking is competitive aggressiveness. However, this may be reflected in their willingness to destabilise their market, regardless of the effect this has on competitors, and the fact that they establish alliances with competitors essentially to control them, which could be seen as a form of passive aggressiveness. Clearly, therefore, ACME-PAC can be seen to be a company in a complex and turbulent environment, achieving success while adopting an entrepreneurial orientation.

\section{CONCLUSIONS AND RECOMMENDATIONS}

Business environments in the twenty-first century are becoming increas- 
ingly complex, turbulent and unpredictable. The traditional bureaucratic, command and control, or scientific management model is unsuitable for handling such turbulent environments. To be successful in such environments companies need to adopt a different way of managing. Many authors (e.g. Dess and Lumpkin, 2005) have suggested the entrepreneurial orientation as a suitable technique for addressing complex and turbulent environments, and other authors (e.g. Russell and Faulkner, 1999 and 2004) have used chaos theory in discussing entrepreneurship. However, there is little literature on using chaos theory as an underlying theory for investigating the role of the entrepreneurial orientation in complex and turbulent environments. This paper, by integrating the business environment, entrepreneurial orientation and chaos theory, has proposed a different view of managing in turbulent environments and as such has contributed to the literature of business environments and of entrepreneurship. For academics, it proposes a new route to investigating the role of entrepreneurship in turbulent environments and, for practicing entrepreneurs and business people, it provides an introduction to a new way of thinking about their businesses and gives some suggestions on how to cope with the complex and turbulent environments that most of them face.

The paper proposed the adoption of an entrepreneurial orientation in order to prevent a mismatch between the functioning of the organisation and the requirements of an increasingly complex and competitive environment. The paper further proposed that a viable means of coping with such environments is by changing to an entrepreneurial approach that can "cause and cash-in on non-equilibrium, creating and profiting from uncertainty and instability" (Stacey, 1996: 201). The case example has shown how an entrepreneurial firm operating in a complex and turbulent environment has successfully used an entrepreneurial orientation as proposed by Lumpkin and Dess (1996) to cope with its environment in a way that is consistent with that indicated by chaos theory. Those firms that can achieve the transformation into an entrepreneurial organisation will ensure that the entrepreneurial processes of autonomy, innovation, calculated risk taking, proactiveness, and competitive aggression are an integral part of their business. This will increase the chance of their survival and success in the twenty-first century environments of increasingly complex and competitive markets.

Although almost all the literature supports this proposal, it has not been shown to be universally true, and therefore, further research in the field is needed. Specific research that is required are studies investigating how entrepreneurial firms actually apply the entrepreneurial processes of 
autonomy, innovation, calculated risk taking, pro-activeness, and competitive aggression in turbulent environments. This is important as relatively little research has been done on the individual components of the entrepreneurial orientation. Further research that would be of value would be longitudinal studies of firms that have changed from a bureaucratic orientation to an entrepreneurial orientation, in order to assess the effect that this has had on the firms' performances and the problems they have experienced in the transformation. Finally, research of other entrepreneurial companies using specific chaos theory approaches could provide further knowledge about, and understanding of, the processes used in entrepreneurial firms: for example, a study into how strategy making emerges in entrepreneurial firms or how the concept of self-organisation enables self control to happen in other entrepreneurial firms in complex and turbulent environments.

\section{ACKNOWLEDGEMENTS}

The author would like to thank Dr Yong Wang of the University of Wolverhampton and two anonymous reviewers for their critiques, which added considerably to the value of this paper.

\section{REFERENCES}

Achrol, R. S. (1991). Evolution of the Marketing Organisation: New Forms for Turbulent Environments. Journal of Marketing, 55, October, 77 - 93.

Alexandrova, M. (2004). Entrepreneurship in a Transition Economy: The Impact of Environment on Entrepreneurial Orientation. Problems and Perspectives in Management, 2, $140-148$.

Aloulou, W. and Fayolle, A. (2005). A Conceptual Approach of Entrepreneurial Orientation within Small Business Context. Journal of Enterprising Culture, 13(1): 21 - 45.

Bartlett, C. and Ghoshal, S. (1995). Building the Entrepreneurial Corporation: New Organisational Processes, New Managerial Tasks. European Management Journal, 13(2): $139-155$.

Baskin, K. (1998). Corporate DNA: Learning from Life. Boston: ButterworthHeinemann.

Birkinshaw, J. (1995). Encouraging Entrepreneurial Activity in Multinational Corporations. Business Horizons, May - June, 32-33.

Bouchikhi, H. (1993). A Constructivist Framework for Understanding Entrepreneurship Performance. Organization Studies, 14(4), 549-570.

Briggs, J. and Peat, F. D. (1999). Seven Life Lessons of Chaos: Timeless Wisdom from the Science of Change. New York: Harper Collins. 
Brooks, I. and Weatherston, J. (1997). The Business Environment: Challenges and Changes. London: Prentice Hall.

Brown, S. L. and Eisenhardt, K.M. (1998). Competing on the Edge: Strategy as Structured Chaos. Boston: Harvard Business School Press.

Bruining, H. and Wright, M. (2002). Entrepreneurial Orientation in Management Buyouts and the Contribution of Venture Capital. Venture Capital, 4(2): 147-168.

Bruyat, C. and Julien, P-A. (2000). Defining the Field of Research in Entrepreneurship. Journal of Business Venturing, 16, 165 -180.

Burgess, S. M. (1998). The New Marketing: Building Strong Marketing Strategies in South Africa today. Halfway House: Zebra Press.

Burnes, B. (2004). Managing Change. $4^{\text {th }}$ edition. Harlow: FT Prentice Hall.

Caldwell, R. L. (2000). Seminar on Futures Techniques [online]. Available at: http://ag.arizona.edu/futures/fut/semtech.html [Accessed 17 May 2000].

Chattell, A. (1995). Managing for the Future. Chatham: MacMillan Business.

Chell, E., Haworth, J. and Brearley, S. (1991). The Entrepreneurial Personality: Concepts, cases and categories. London: Routledge.

Combs, A. (1995). The Radiance of Being: Complexity, Chaos and the Evolution of Consciousness. Edinburgh: Floris Books.

Costa, J. (1995). An Empirically-based Review of the Concept of Environmental Scanning. International Journal of Contemporary Hospitality Management, 7(7): 1 - 6.

Courtney, H., Kirkland, J., and Viguerie, P. (1997). Strategy Under Uncertainty. Harvard Business Review, November - December, 67 - 79.

D'Aveni, R. A. (1999). Strategic Supremacy through Disruption and Dominance. Sloan Management Review, 40(3), Spring, 127 - 135.

Denzin, N. K. and Lincoln, Y. S. (1994). Handbook of Qualitative Research. Thousand Oaks: Sage.

Dess, G. G. and Lumpkin, G. T. (2005). The Role of Enrepreneurial Orientation in Stimulating Effective Corporate Enrepreneurship. Academy of Management Executive, 19(1): 147 - 156.

Doherty, N. and Delener, N. (2001). Chaos Theory: Marketing and Management Implications. Journal of Marketing Theory and Practice, 9(4), Fall, 66 - 75.

Edgar, D. A. and Nisbet, L. (1996). A Matter of Chaos - Some Issues for Hospitality Businesses. International Journal of Contemporary Hospitality Management, 8(2): 6 - 9 .

Edgar, D. A. and Nisbet, L. (1998). Strategy in Small Business - A Case of Sheer Chaos [online]. Available

at: http://www.mcb.co.uk/services/conferen/liblink/ijchm/intpap.htm. [Accessed: 20 May 1998].

Eisenhardt, K. M. and Sull, D. N. (2001). Strategy as Simple Rules. Harvard Business Review, January-February, $107-116$.

Emery F. E. and Trist. E. L. (1965). The Causal Texture of Organizational Environments. Human Relations, February, 18, 21 - 32.

Evans, D. (1998). The Arbitrary Ape. New Scientist, 159(2148), 22 August, 32 - 35.

Farrell, L. C. (1993). Searching for the Spirit of Enterprise: Dismantling the TwentiethCentury Corporation - Lessons from Asian, European and American Entrepreneurs. New York: Dutton.

Farrell, W. (1998). How Hits Happen: Forecasting Predictability in a Chaotic Marketplace. New York: Harper Business. 
Foxall, G and Minkes, A. (1996). Beyond Marketing: the Diffusion of Entrepreneurship in the Modern Corporation. Journal of Strategic Marketing, 4(2): 71 - 93.

Fradette, M. and Michaud, S. (1998). The Power of Corporate Kinetics: Create the Selfadapting, Self-renewing, Instant-action Enterprise. New York: Simon and Schuster.

Gault, S. B. and Jaccaci, A. T. (1996). Complexity Meets Periodicity. The Learning Organization, 3(2): 33 - 39.

Gibson, R. (1997). Rethinking the Future: Rethinking Business, Principles, Competition, Control, Leadership, Markets and the World. London: Nicholas Brealey.

Ginsberg, A. and Hay, M. (1994). Confronting the Challenges of Corporate Entrepreneurship: Guidelines for Venture Managers. European Management Journal. 12(4): 382 $-389$.

Glass, N. (1996). Chaos, Non-linear Systems and Day-to-day Management. European Management Journal, 14(1), February, 98 - 105.

Gleick, J. (1987). Chaos. London: Cardinal.

Halal, W. (1996). The New Management. San Francisco: Berrett-Koehler.

Jennings, D. (1994). Multiple Perspectives of Entrepreneurship. Cincinnati: South-Western.

Kelly, S. and Allison, M. A. (1999). The Complexity Advantage: How the Science of Complexity Can Help Your Business Achieve Peak Performance. New York: BusinessWeek Books.

Koch, R. (2000). The Power Laws - The Science of Success. London: Nicholas Brealey.

Lazer, W., LaBarbera, P., MacLachlan, J. M. and Smith, A. E. (1990). Marketing 2000 and beyond. Chicago: American Marketing Association.

Lee, T. W. (1999). Using Qualitative Methods in Organizational Research. Thousand Oaks: Sage.

Lichtenstein, B. B. (2000). Self-organized Transitions: A Pattern Amid the Chaos of Transformative Change. Academy of Management Executive, 14(4): 128 - 141.

Luczkiw, E. (2002). Instilling the Spirit - Learning Strategies for the New Millennium. Citizenship, Social and Economics Education: An International Journal, 5(1): 29 43.

Lumpkin, G. and Dess, G. (1996). Clarifying the Entrepreneurial Orientation Construct and Linking it to Performance. Academy of Management Review, 21(1), 135 - 172.

McKenna, R. (1991). Marketing is Everything. Harvard Business Review, January - February, $65-79$.

Morris, M. H. and Lewis, P. S. (1995). The Determinants of Entrepreneurial Activity: Implications for Marketing. European Journal of Marketing, 29(7): 31 - 49.

Morris, M. H., Schindehutte, M. and LaForge, R. W. (2002). Entrepreneurial Marketing: A Construct for Integrating Emerging Entrepreneurship and Marketing Perspectives. Journal of Marketing Theory and Practice, 10(4): 1 - 16.

Muzyka, D., De Koning, A. and Churchill, N. (1995). On Transformation and Adaption: Building the Entrepreneurial Corporation. European Management Journal, 13(4): $346-362$.

Nilson, T. H. (1995). Chaos Marketing. London: McGraw-Hill.

Osborne, Richard L. (1995). The Essence of Entrepreneurial Success. Management Decision, 33(7): 4 - 9.

Peterson, M. F. and Meckler, M. R. (2001). Cuban-American Entrepreneurs: Chance, Complexity and Chaos. Organization Studies, January, $1-25$.

Phelan, S. E. (1995). From Chaos to Complexity in Strategic Planning. Paper presented at 
55th Annual meeting of Academy of Management, Vancouver, Canada, August 6 9.

Pinchot. E. and Pinchot, G. (1994). The End of Bureaucracy and the Rise of the Intelligent Organisation. San Francisco: Berrett-Koehler.

Puth, G. (1996). Dynamics of the Marketing Environment: Implications for Marketing Training in South Africa. Unpublished monograph. Department of Business Economics, University of Pretoria.

Roberts, J. H. (2000). Developing New Rules for New Markets. Journal of the Academy of Marketing Science, 28(1), Winter, $31-45$.

Russell, R. and Faulkner, W. (1999). Movers and Shakers: Chaos Makers in Tourism Development. Tourism Management, 20, 411 - 423.

Russell, R. and Faulkner, W. (2004). Entrepreneurship, Chaos and the Tourism Area Lifecycle. Annals of Tourism Research, 31(3), July, 556 - 579.

Smilor, R.W. and Feeser, H. R. (1991). Chaos and Entrepreneurial Process: Patterns and Policy Implications for Technology Entrepreneurship. Journal of Business Venturing, 6(3), May, $165-171$.

Smit, P. J. and Cronje, G. J. De J. (1992). Management Principles. Cape Town: Juta.

Stacey, R. D. (1992). Managing Chaos: Dynamic Business Strategies in an Unpredictable World. London: Kogan Page.

Stacey, R. D. (1996). Complexity and Creativity in Organisations. San Francisco: BerrettKoehler.

Stevenson, H. and Harmeling, S. (1990). Entrepreneurial Management's Need for a More "Chaotic" Theory. Journal of Business Venturing, 5(1), January, 1 - 14.

Tetenbaum, T. J. (1998). Shifting Paradigms: From Newton to Chaos. Organizational Dynamics, Spring, $21-32$.

Thompson, J. D. (1967). Organizations in Action. New York: McGraw-Hill.

Volberda, H. W. (1997). Building Flexible Organisations for Fast Moving Markets. Long Range Planning, 30(2): 169 - 183

Waldrop, M. M. (1992). Complexity: the Emerging Science at the Edge of Order and Chaos. New York: Simon and Schuster.

Weaver, K. M., Dickson, P. H., Gibson, B. and Turner, A. (2002). Being Uncertain: The Relationship between Entrepreneurial Orientation and Environmental Uncertainty. Journal of Enterprising Culture, 10(2), June, 87 - 105.

Weeks, R. V. (1990). Managing Strategic and Corporate Change within a Turbulent Environmental Context: a Strategic Management Approach. Doctor of Commerce thesis, Faculty of Economics and Management Science, Rand Afrikaans University, Johannesburg, South Africa.

Young, T. R. and Kiel, L. D. (1997). Chaos and Management Science: Control, Prediction and Non- linear Dynamics [online]. Available at: http://www.tryoung.com/Chaos/manag.htm. [Accessed 22 July 1997].

Yusuf, A. (2002). Environmental Uncertainty, the Entrepreneurial Orientation of Business Ventures and Performance. International Journal of Change Management, $12(3 \& 4), 83-103$.

Zeithaml, V.A. and Bitner, M.J. (1996). Services Marketing. New York: McGraw-Hill. 
Roger B Mason

\section{BIOGRAPHICAL NOTES}

Roger Mason is a Senior Lecturer in the Department of Marketing at the Durban University of Technology, South Africa and an Honourary Research Fellow in the Department of Marketing, University of Wolverhampton Business School, United Kingdom. He lectures in the fields of marketing, sales, strategy and research. His principal area of research interest is complexity and turbulence in marketing and the use of chaos and complexity theories to better understand the changing marketing environment. 